\section{Non-synonymous polymorphism in the coding sequence of human 3-beta hydroxysteroid dehydrogenase (HSD3B)}

\author{
A.J.Russell, D.Gaffney ${ }^{1}$, C.R.W.Edwards ${ }^{2}$ and \\ R.G.Sutcliffe \\ Institute of Genetics, University of Glasgow, Church Street, \\ Glasgow G11 5JS, 'Institute of Biochemistry, Glasgow \\ Royal Infirmary, Glasgow G4 OSF and 2University \\ Department of Medicine, Western General Hospital, \\ Edinburgh EH4 5XU, UK
}

Source: Amplified human genomic DNA.

Polymorphism: Sequencing of amplified exon 4 (1) identified a single base pair substitution at position 1100 in the coding sequence of $3 \beta$-HSD. The replacement of A (allele 1 ) by $\mathrm{C}$ (allele 2) results in codon 367 changing from Asn to Thr. This is the first non-synonymous polymorphism to be described in $3 \beta$-HSD and its physiological effect has yet to be assessed. Mild late onset deficiencies of $3 \beta$-HSD have been associated with hirsutism, oligomenorrhoea and male pseudohermaphroditism. In vitro expression and enzyme kinetics of both alleles are under investigation; as are linkage studies with the $3 \beta$-HSD BgIII synonymous polymorphism (2).

Chromosomal Location: 1p13.1 (3); 1 p13 (4).

Mendelian Inheritance: In two families (7 individuals).

Frequency:

allele $1=0.69$

allele $2=0.31$

(from 27 unrelated males and females).

Percentage heterozygosity $=56 \%$

Other Comments: PCR amplimers were:

5'-CGTGGTTGGCACCTCTT-3' and

5'-GGAGCTTGATGACATCT-3'

Taq polymerase (Promega): 30 cycles at $92.5^{\circ} \mathrm{C} 30 \mathrm{sec}, 50^{\circ} \mathrm{C}$ $30 \mathrm{sec}$, and $72^{\circ} \mathrm{C}$ for $1 \mathrm{~min}$. The DNA product was purified on an agarose gel then sequenced using Sequenase Version 2 (USB). The sequencing primer was:

5'-AGCTTCCTACTCAGGCC-3'.

EMBL Databank Accession No.: X55997H.

Acknowledgements: To Profs D.J.H. Brock and J.M. Connor, and Drs A.M. Wallace and R.A. Fisher for human DNA. Supported by grants from WHO (H9.181/601) and the Scottish HERT (SP1046). A.J.R. thanks SERC for a graduate studentship.

References: 1) Lachance,Y. et al. (1990) J. Biol. Chem. 265, 20469-20475. 2) Russell,A.J. et al. (1991) Nucl. Acids Res. 19, 1172. 3) Morrison, N. et al. (1991) Human Genetics 87, 223-225. 4) Berube,D. et al. (1989) Cytogenet. Cell Genet. 52, $199-200$.

\section{Haelll RFLP for salivary proline-rich protein gene probe (pPRPII2.2RP)}

\author{
D.Galutira, P.W.Allderdice and W.S.Davidson ${ }^{1}$ \\ Basic Sciences Division, Faculty of Medicine and \\ 1Department of Biochemistry, Faculty of Science, \\ Memorial University of Newfoundland, St John's, \\ Newfoundland, A1B 3V6, Canada
}

Source and Description: pPRPII2.2RP is a $2.2 \mathrm{~kb}$ PstI-EcoRI fragment derived from a proline-rich protein genomic clone (PRP-1) subcloned in pAT153 (1). The $2.2 \mathrm{~kb}$ insert was originally isolated from a human genomic library propagated in lambda phage Charon 4A by probing with a cloned proline-rich protein DNA synthesized from rat parotid gland mRNA (2). It contains a 980 bp Hinfl fragment which cross hybridizes with other human salivary protein complex (SPC) genes (1).

Polymorphisms: HaeIII identifies a six allele polymorphism with constant bands of $3.2 \mathrm{~kb}, 1.0 \mathrm{~kb}$ and $0.8 \mathrm{~kb}$.

Frequency: Studied in 34 unrelated Caucasians of European origin.

$\begin{array}{lll}\text { A1 } & 2.9 \mathrm{~kb} & 0.29 \\ \mathrm{~A} 2 & 2.7 \mathrm{~kb} & 0.56 \\ \mathrm{~A} 3 & 2.5 \mathrm{~kb} & 0.03 \\ \mathrm{~A} 4 & 2.3 \mathrm{~kb} & 0.09 \\ \mathrm{~A} 5 & 4.1,2.3 \mathrm{~kb} & 0.01 \\ \mathrm{~A} 6 & 3.8,2.3 \mathrm{~kb} & 0.01 \\ \text { Observed }\end{array}$

0.56

0.03

0.01

0.01

heterozygosity:

$56 \%$

Chromosomal Location: The human SPC which consists of six coding loci spanning over $700 \mathrm{~kb}$ of DNA (3) has been mapped to chromosome 12 by cell hybrid analysis (4) and to $12 \mathrm{p} 13.2$ by in situ hybridization using pPRPII2.2RP (1).

Probe Availability: pPRPII2.2RP is available from the American Type Culture Collection (ATCC) in Rockville, Maryland.

Other Comments: Although it is barely discernible in this example, the $1.0 \mathrm{~kb}$ constant fragment has been observed in other blots.

Acknowledgement: Supported in part by grants from MRC Canada, NSERC Canada, The Allan Roeher Institute and the Scottish Rite Foundation and The School of Graduate Studies, Memorial University of Newfoundland.

References: 1) Mamula et al. (1985) Cytogenet. Cell Genet. 39, 279-284. 2) Azen et al. (1984) Am. J. Hum. Genet. 37, 418-424. 3) Kim et al. (1990) Genomics 6, 260-267. 4) Azen et al. (1985) Proc. Natl. Acad. Sci. USA 81, 5561-5565. 